\title{
Management Development of Teachers' Professional Competence
}

\author{
Yohamintin*, Johar Permana, Sri Wulansari \\ Educational Department, School of Postgraduates \\ Universitas Pendidikan Indonesia \\ Bandung, Indonesia \\ *yohamintin@upi.edu
}

\author{
Sri Mulyani \\ STIE Pertiwi \\ Bekasi, Indonesia
}

\author{
Irawati Sabban \\ Universitas Pasifik Morotai \\ Maluku Utara, Indonesia
}

\begin{abstract}
The study aims to reveal the desired standards of professional competence, as well as efforts in management development of professional competence, and teacher responses to the policies taken by the principal to development the teachers professional competence. This study used a qualitative approach with descriptive methods of analysis with case study design. The data collection was done by using in-depth interviews, participant observation, and documentation. The results of this study indicate that the efforts undertaken to manage the development of professional competence of teachers is: a) comprehensive recruitment by selection; b) education and training, c) educational supervision, d) learning task, e) increase the motivation of teachers to instill commitment and reward.
\end{abstract}

Keywords-educators, management development, policy responses, professional competence

\section{INTRODUCTION}

Teachers must have awareness of reality, demands and expectations of stakeholders whose belief in education must be able to support the demands of life. It is not surprising if there are facts in the field that there are people who look cynically at teachers when the results, they see do not meet their expectations. Because of a teacher is imitated and emulated, in the sense that he is a person who has charisma or dignity so that he needs to be a model of virtue.

To improve the quality of national education, the government, especially through the Ministry of National Education, continues to make various changes and updates to the education system in Indonesia. One of the efforts that have been doing related to teachers is The Law No. 14 of 2005 concerning Teachers and Lecturers and Government Regulation No. 19 of 2005 concerning National Education Standards [1] is basically a government policy which includes government efforts to organize and improve the quality of teachers in Indonesia. Michael G. Fullan quoted by Suyanto and Djihad Hisyam stated that "educational change depends on what teachers do and think...". This opinion suggests that changes and reforms in the education system really depends on "what teachers do and think ". In other words, it depends on the mastery of teacher competency.

The reality of teacher competency at this time seems to still vary, as expressed by Sudarwan Danim [2], that one of the characteristics of the education crisis in Indonesia is that teachers have not been able to show adequate work performance. This shows that teacher performance has not been fully supported by an adequate degree of competence mastery. Therefore, it is necessary to have comprehensive efforts to improve teacher competency. In order to run the education process effectively and efficiently, teachers are required to have adequate competency, both in terms of type and content. However, if we digest into the content of any kind of competency delivered by experts and government policy perspective, it seems that to be a competent teacher is not that simple. To establish and improve the competence of teachers needed effort and comprehensive study. Increasing the quality of education means to increase the quality of human resource. While the quality of education has not been satisfying, the quality of Indonesian human resources has been discouraging. The teacher is one of the dominant factors in creating professional human resources. Therefore, failures in the world of education are often addressed to teachers. This is because teachers are seen as an active resource compared to other components of the school or madrasah organization such as infrastructure, curriculum which is a passive school resource. Though the fate of the teacher is concerning, teachers are required to participate in spurring the nation's intelligence.

The importance of the role of the principal was also expressed by Mulyana [3], in his research journal, arguing that the role of the principal is very important in developing teacher professional competence, which can be carried out through 
upgrading activities, training, teacher work groups, and classroom supervision. The principal has a decisive role in order to improve the quality of teachers' teaching abilities, including in developing teacher's competencies. Because of the principal's function is as a facilitator, motivator, and supervisor.

Research on teacher professional development was conducted by Ani Hasan [4], which reveals the factors that cause low teacher professionalism. The factors causing the low level of teacher professionalism include: (1) the teacher is likely carrying out his profession against his conscience, the teacher is always interfered with, the space for the teacher is always controlled through the necessity to create a lesson unit ; (2) there are still many teachers who work outside of their working hours to fulfill their daily needs, so there are still many teachers who do not fully pursue their profession; (3) the absence of teacher professional standards as demanded in developed countries; (4) the existence of private tertiary institutions that produce teachers whose graduate are original without taking into account their future output in the field, causing many teachers to disobey the ethics of the teaching profession; (5) lack of motivation of teachers in improving selfquality because teachers are not required to do research as required to lecturers in tertiary institutions.

Fitriani [5], has also confirmed that there are still some teachers who don't create lesson plan before teaching. Some do not make affirmation learning material and use unsuitable teaching media. It is happen as the result of some teacher's lack of competency in requiring teacher competency to acquire the impact of teaching performance. Akadum's [6] research on teacher professionalism also confirms that there are five causes of the low level of teacher professionalism; (1) many teachers do not fully pursue their profession, (2) teachers are vulnerable and low compliance with the norms and ethics of the teaching profession, (3) recognition of education and teacher science is still half-hearted in policy making and the parties involved. This is evident from the inadequacy of the institution that produces teacher and education personnel, (4) there is still no smooth difference in opinion regarding the proportion of teaching material provided to prospective teachers, (5) PGRI (Indonesian Teachers Association) still does not function as a professional organization that strives to enhance its member professionalism.

Based on these problems, the quality of human resource developments, especially teachers in basic education (Madrasah Tsanawiyah and SMP) requires attention in professional competency development. Moreover, the real challenges faced by madrasas are very complex. It appears that most madrasas have not been managed adequately. As the result, the improvements or professionalism efforts are generally still very low.

\section{LITERATURE REVIEWS}

\section{A. Teacher Professional Competence}

The teacher is someone who has the ability to organize and manage the class, who is consciously responsible for educating, teaching, and guiding students. People who are called teachers are people who have certain competencies such as; the ability to design learning programs and being able to organize and manage the class so that students can learn and reach maturity level as the ultimate goal of the educational process.

According to Cowell [7], competence is an active skill / skill. Competencies are categorized from simple or basic to more difficult or complex levels which in turn are related to the process of preparing materials or learning experiences, which usually consist of: (1) mastering a minimum of basic competencies, (2) basic competency practice, and (3) addition of refinement or development of competencies or skills. The three processes can continue as long as there is still a chance to make improvements or develop their competences.

One of the competencies that teachers must have at the basic education level, namely: professional competency. The professional competency indicators are based on Government Regulation no. 16 of 2007, namely:

- Mastering the material, structure, concepts, and scientific mindset that supports the subject being taught.

- Mastering the competency standards and basic competencies of the subject / field of development is being handled.

- Developing creative learning materials.

- Developing professionalism in a sustainable manner by taking reflective action.

- Utilizing information and communication technology to communicate and develop themselves.

\section{Management of Teacher Professional Competence}

\section{Development}

As for management, in its implementation, planning, managing and developing employees is part of the implementation of human resource management. Regarding human resources, when it is related to the field of education management, the meaning of the word Human Resources cannot be separated from the management or management of existing resources such as teachers, staffs and school employees.

According to Siagian [8], it is said that proper human resource management requires an information system starting from planning, making job descriptions, job descriptions, specifications, placement, training and development, job appraisals, reward systems, career planning and development, disciplinary enforcement, work ethics, maintaining good relationships. Harmony among employees, industrial relations, 
termination of employment and retirees as well as conducting HR audits.

If these HR concepts and models are applied in educational institutions, professionalism is needed in school or madrasah resources such as teachers and school employees. In relation to teachers, professional teachers are people who have special abilities and expertise in the field of teacher training so that they are able to carry out their duties and functions optimally, or professional teachers are people who are well educated and trained and work in accordance with their fields.

It is only natural for schools or madrasahs to have teacher professional competency development program with clear and targeted program planning. It is the case with staff development efforts or staff development. Basically staff development efforts are continuous activities with teacher professional development activities because they are a school resource. In this development, school management will experience several obstacles or challenges. According to Pfeffer, the first challenge concerns the wrong assumptions (incorrect premises) about human resource management (HRM) held by management. Four wrong assumptions that still "blemish" HR policies and practices in many organizations are:

- With "good" managers, HRM works by itself;

- Human resources are not that important;

- Control is everything;

- Every problem has a solution.

Second, many critical HRM problems at the corporate level have not been resolved. These various problems, among others, relate to the role of HRM in strategic decision making and the lack of knowledge of HRM among top managers. These are all influenced by the structure, size, diversity and allocation of organizational authority.

The third challenge concerns the achievement of employee commitment. Creating a commitment to all school resources, so that they are willing to "spend" energy to achieve organizational goals, is very difficult. School goals are usually long-term and general in nature, such as educational progress or quality of output. In fact, teachers focus on short-term time horizons to meet their various needs (eg. salary, working conditions, rewards, and fair treatment). The creation of links between these sets of goals is not easy.

The fourth challenge, perhaps the most important in the next five to ten years, is flexibility: the flexibility to adapt and adjust to a rapidly changing and increasingly turbulent environment; flexibility to try new HRM concepts; and, the flexibility to accept and implement fundamental changes, which are sometimes painful. This flexibility to change must be possessed not because we want to have it, but because we have to do it, as an adaptation to various environmental changes, such as changes in customers, changes in resources and personnel composition, changes in technology, and sociocultural changes. Our dilemma is that organizational personnel, in this case schools, even HR professional staff, often show resistance to change, making schools inflexible when we have to change the way we do things.

With the existence of HR professional requirements, in this case teachers as the criteria for professional teachers, there needs to be a new paradigm to create a profile of professional Indonesian teachers in the 21st century, namely; (1) has a mature and developed personality; (2) strong mastery of science; (3) skills to arouse students to science and technology; and (4) continuous professional development. These four aspects constitute a complete unity that cannot be separated and added to by other efforts that influence the development of teacher professional competence.

If the requirements for developing the professional competence of teachers above are met, it will change the role of teachers who were passive to become creative and dynamic teachers. This is in line with Semiawan's [9] opinion that fulfilling the requirements of professional teachers will change the teacher's role from being a verbalized orator to being dynamic in creating an atmosphere and learning environment that is an invitation learning environment. In order to improve the quality of education, teachers have multiple functions, namely as facilitators, motivators, speakers, communicators, transformers, change agents, innovators, counselors, evaluators, and administrators.

\section{A. Professional Competency Development Strategy}

As for having professional staff, according to Shapero, policies can be implemented by answering two main questions, namely how to have and how to empower professional resources. So it can be said that to have a professional teacher really depends on how to answer these two questions, namely how to get professional teachers and how to empower teachers to be professionals.

Furthermore, to get professional and empowering teachers, it can be done by carrying out essential activities which include: (1) teacher qualifications; (2) teacher recruitment, starting from teacher planning, teacher selection, and teacher appointment; (3) increasing the ability of teachers; (4) increasing teacher work motivation; and (5) supervision of teacher performance. From some of the above foundations it can be concluded that to develop teacher professional competence is through activities as visualized in the following figure 1:

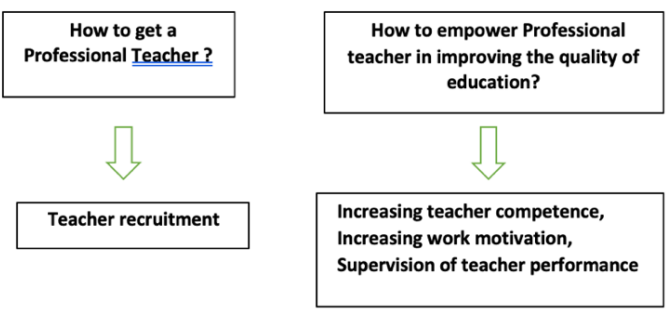

Fig. 1. Professional employee development systematics. 


\section{METHODS}

This study used a qualitative approach with descriptive methods of analysis with case study design. The data collection was done by using in-depth interviews, participant observation, and documentation. Data analysis techniques include data reduction, data display, and conclusion, checking the validity of the findings made by way of extension of the participation of researchers; triangulation techniques using a variety of sources, theories, and methods; observation and perseverance. The informant is the principals, vice principals, and educators [10].

This research was conducted at Madrasah Tsanawiyah Negeri Batu, city of Batu. Researchers want to know; what is the form of the implementation of programs implemented by school/madrasah principals to develop teacher professional competence, systematics of the efforts made by principals in managing teacher professional competency development, and about how teachers respond to principals' policies in developing teacher professional competence in MTs Negeri Batu, and what reasons influence the policy for developing professional competence of teachers at MTs Negeri Batu.

In this research, there are two types of data sources, the primary data source in the form of words and behavior. Meanwhile, additional data sources are documents and statistical data. The words and behavior of people who were observed, interviewed, and documented were the main data sources and were recorded through written notes or through audio tapes recording about strategic management in an effort to improve the quality of educators at MTs Negeri Batu.

In the data analysis stage, it requires persistence of observations and interviews to obtain data about various things needed in research; checking the validity of the data using three triangulations, namely triangulation of data sources, triangulation of theory, and triangulation of methods. Data analysis is an attempt to find themes and working hypotheses. Improving data is related to language, writing systematics and simplifying data in order for this research to be communicative and accountable. It is necessary to hold consultations with experts to obtain input for the improvement of the report [10].

\section{RESUlt AND DisCUSION}

\section{A. Results}

Based on the findings of the research:

1) The standard of professional competence desired by the Principal of MTs Negeri Batu

- Mastering the material, structure, concepts, and scientific mindset that supports the subject being taught.

- Mastering the competency standards and basic competencies of the subject/field of development being handled.

- Developing creative learning materials.
- Develop professionalism in a sustainable manner by taking reflective action.

- Proficient in utilizing information and communication technology to communicate and develop themselves.

However, in the field, MTs Negeri Batu in the realization of teacher competency development is still lacking, it can be seen from observations, the teachers' mastery of IT is still minimal, and IT training in learning is still lacking, especially the lack of facilities and infrastructures that support IT media learning.

2) Professional competence development efforts

- Conducting and participating in training

- Performing Supervision

- Supervision of the principal

- Regular work meetings

- Group supervision / peer tutors (MGBS)

- Supervision by the Ministry of Religion

- Supervision by the National Education Office

- Assigning teachers to teaching: currently has 1 teacher for study assignments (S2 scholarship) and 3 teachers with independent costs.

- Increasing work motivation

- routine recitation

- basic salary

- structural and functional allowances

3) Teacher response: Teachers MTs Negeri Batu gave a positive response on the policy for the development of professional competence of teachers.

\section{B. Discussion}

1) The Efforts of the Head in Managing Teacher Professional Competence Development

a) Recruitment of young teachers by comprehensive selection: To get professional teachers at MTs Negeri Batu, do recruitment by recruiting young teachers with little experience but at the same time having high commitment, willingness and competence through comprehensive selection and empowering existing teachers to become professionals by conducting teacher coaching through increasing teacher skills, improving teacher work motivation and supervision and improvement of teacher performance. In this case MTs Negeri Batu has done well, seen by paying attention to qualifications, the recruitment process, capacity building, increasing work motivation, and monitoring teacher performance.

Where in the process pay attention to: strict selection, and appoint teachers according to student ratios and workloads. 
b) Organizing and Involving Teachers in Education and Training: The head schedules and gives each teacher the same opportunity to take part in trainings so that later it will support performance in schools for the advancement of learning. Most of the teachers have attended trainings to improve their competence, especially professional competence.

c) Conduct educational supervision: Supervisi carried out by the head of school / madrasah. In addition to supervision by the school principal, MTs Negeri Batu received more supervision, namely MTs Negeri Batu was supervised by the Ministry of Religion and Diknas. Where, the supervision carried out by Diknas only covers learning activities to help MTs Negeri Batu to be better in standard performance procedures.

d) Assigning teachers: MTs Negeri Batu seems to support the development of human resources, in this case teachers. In order to support the process of improving teacher competence, the Head of State MTs provides facilities and opportunities for teachers to continue their learning process, namely to the S2 / S3 level. For example, in the 2014 period, State MTs assigned one mathematics teacher who received a scholarship from the Ministry of Religion to continue his master's studies. Apart from the learning assignments obtained from the Ministry of Religion scholarships, the Head of Madrasah also provides support to teachers who wish to continue their S2 / S3 studies through independent fees in the form of full support, namely by providing leniency in teaching schedules so that teachers can adjust lectures while not leaving their teaching obligations in the classroom.

e) Increase teacher work motivation: To get teachers who have professional competence and empower MTs Negeri Batu teachers to carry out essential activities which include: (1) teacher qualifications; (2) teacher recruitment, starting from teacher planning, teacher selection, and teacher appointment; (3) increasing the ability of teachers; (4) increasing teacher work motivation; and (5) supervision of teacher performance.

Madrasah always strives to develop human resources and the creativity of teachers and employees. It is done solely to improve the quality of education at MTs Negeri Batu and to try to create a conducive work environment and a family atmosphere. A conducive work environment and a family atmosphere need to be created by schools to be more productive in work ethic and there will be no friction or conflict that will affect the survival of MTs Negeri Batu.

Commitment to being role models and deepening religious values is built, instilled and accustomed to through recitation, regular meetings every Monday, continuous guidance carried out by the head of the madrasah, also through improving welfare so that teachers and employees of MTs Negeri Batu get used to it. Giving awards to teachers at MTs Negeri Batu through a basic salary that is received regularly every month according to their academic qualifications. Apart from that, these benefits include structural and functional allowances, education, years of service, expertise or experience, and others. With the existence of a policy to increase the work motivation of these teachers, MTs Negeri Batu teachers have high enthusiasm and motivation to work, high work productivity, have great responsibility at work, have a sense of trust, high commitment and loyalty, high concern on the quality of education.

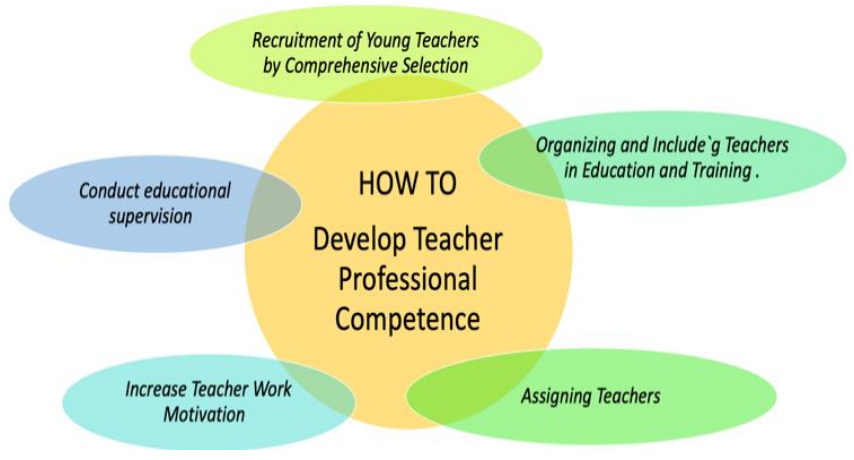

Fig. 2. Design teacher professional competence development processed by research result.

2) Teacher response: The teachers are very supportive over the policies taken headmaster in order to improve the competence of teachers, seen from the positive responses of teachers stating that every teacher is given an equal opportunity to develop their competence.

\section{CONCLUSION}

The head of MTs Negeri Batu wants educators at MTs Negeri Batu to have academic qualifications and competence as agents of learning, be physically and mentally healthy, and have the ability to realize the goals of national education, MTs Negeri Batu wants teachers to meet professional competency standards, namely: a) mastering the material, structure, concepts, and scientific mindset that support the subject being taught, b) mastering the competency standards and basic competences of the subject / field of development being handled ; c) able to develop creative learning materials ; d) developing professionalism in a sustainable manner by taking reflective action ; and utilize information and communication technology to communicate and develop themselves.

To get teachers who have professional competence, MTs Negeri Batu uses the principles of how to have and how to empower resources with professional competence. So that it can be concluded, to get teachers who have professional competence at MTs Negeri Batu using two ways, namely how to get professional teachers and how to empower teachers to be professionals. As for the efforts made in managing the development of teacher professional competence, namely:

- To find teachers with professional competence, schools/ madrasahs recruit teachers who are relatively young and competent and highly committed, MTs Negeri Batu conducts recruitment selections.

- Meanwhile, to empower existing teachers to become professionals, provide guidance by: 1) holding and involving teachers in education and training, 2) supervising education, 3) assigning teachers' teaching, 
4) increasing teacher work motivation by instilling commitment and providing reward (reward) deserves.

The policies taken by the Head of MTs Negeri Batu gave a positive response and support for the policies taken by the head of the madrasah, where teachers felt that there was an equal opportunity given to the head of the madrasah in developing the professional competence of each teacher, for example support for postgraduate study.

\section{ACKNOWLEDGMENT}

I would like to acknowledge supports that the following institutions in making this research. Thank LPDP (Indonesia Endowment Fund for Education), Ministry of Finance, Republic Indonesia for providing me with the financial support during my study at Universitas Pendidikan Indonesia. And also thank Universitas Bhayangkara Jakarta Raya for all support and to allow me improving my competency by pursuing my Doctoral study.

\section{REFERENCES}

[1] Depdiknas, Peraturan Pemerintah RI Nomor 19 tahun 2005 tentang Standar Nasional Pendidikan. Indonesia; 2005.

[2] S. Danim, Inovasi Pendidikan: Dalam Upaya Meningkatkan Profesionalisme Tenaga Kependidikan. Bandung: Pustaka Setia; 2002.

[3] Y. Mulyana, "Peran Kepala Sekolah Dasar dalam pengembangan profesionalisme guru," Jurnal Kependidikan Triadik, Vol. 12, No. 1, 2009.

[4] A. Hasan, Pengembangan Profesionalisme Guru di Abad Pengetahuan. PSSJ PPS Univ Negeri Malang. 2003;

[5] C. Fitriani, "Kompetensi Profesional Guru dalam Pengelolaan Pembelajaran di MTs Muhammadiyah Banda Aceh," J Magister Adm Pendidik Pasca Sarjana Univ Syiah Kuala, Vol. 5, No. 2, 2017.

[6] Akadum, Potret Guru Memasuki Milenium Ketiga. http://www.suarapembaharuan.com/News/1999/01/220199/OpEd,.

[7] R.N. Cowell, Buku Pegangan Para Penulis Paket Belajar. Jakarta: Depdikbud, 1988.

[8] S.P. Siagian, Manajemen Abad 21. Jakarta: PT. Bumi Aksara; 1996.

[9] C. Semiawan, Mencari Strategi Pengembangan Pendidikan Nasional Menjelang Abad XXI. Jakarta: Grasindo; 1991.

[10] L.J. Moleong, Metodologi Penelitian Kualitatif. Bandung: PT. Remaja Rosda Karya, 2001 